\title{
Research on the Construction of the Quality Assurance System of Undergraduate Teaching in Chinese Medicine Universities
}

\author{
Bi Yan", Yue Donghui ${ }^{2 *}$ \\ Chang chun University of Chinese Medicine
}

Key words: Colleges and universities in traditional Chinese medicine; teaching quality; quality assurance system

\begin{abstract}
China and the full full implementation of the undergraduate teaching reform project, the teaching quality of higher education is more and more concerned by the society, and the higher education is gradually developing towards the connotation construction and improving the educationquality. Quality is the main goal of the development for colleges and universities. The society pays more and more attention to the teachingquality of undergraduate courses, and how to improve theteaching quality of undergraduate is the main problem in modern colleges and universities. Although some colleges and universities have created internal undergraduate teaching quality assurance system,the construction ideas are not mature, which needs further in-depth study. Based on this, this paper makes a comprehensive study on the construction of teaching quality assurance system for undergraduate colleges and universities in traditional Chinese medicine.
\end{abstract}

\section{Introduction}

In 1998, all the people and institutions in the World Conference on Higher Education said that quality is an important part of higher education. In the second session of the World Conference on Higher Education in 2009, it was statedthe guarantee of quality plays an important role in modern higher education, and that all relevant stakeholders must be guaranteed. Modern colleges and universities of Chinese medicine particularly emphasis on the students' practical ability in undergraduate teaching, but how to realize the improvement of the undergraduate teaching quality in colleges and universities of Chinese medicine, to create security systemintegrated by set of evaluation, system, feedback and rectification, to strengthen the teaching management, to improve the teaching quality of traditional Chinese medicine, is problems to conduct in-depth study for relevant personnel in modern society.

The teaching quality of undergraduate education originated from the middle of the 1980s, which was gradually introduced into our country,and gradually formed the quality assurance movement of higher education with world influence by 90s. The quality management of higher education is the core of the management in colleges and universities. In modern society, the socialist market economy in our country has been developing continuously, and the educational management system has also been further reformed,then there are a variety of problems in the university education quality management work. People have gradually realized that the teachingquality is not only the content of teaching management, but also as the center of University management. In this context, because the higher education quality assurance ideas and methods was introduced into our country for a long time, the government departments also began to require colleges and universities to establish the education qualitysecurity system, and colleges and universities have gradually begun to explore the establishment of teaching quality assurance system. Researchers in China have also paid more attention to this aspect, and the education authorities are calling for the establishment of higher education quality assurance system. Based on this, the traditional teaching quality management methods are also changing, and it is a relativelylong process to find new management mode. The research on the construction of undergraduate teaching quality assurance system is not only the demand of teaching management in Colleges and universities, but also the demand of colleges and universities in the process of development, as well as the development needs of higher 
education.

\section{Reasons influencing the quality educationof colleges and universities}

Government aspects

The first is the contradiction between social demand for higher education development and the reform of higher education system. Application and evaluation of curriculum provision, personnel, research results in modern universityrequire examination and approval by education departments, and autonomy running ability in colleges and universities should be improved, and administrative problems will result in both the internal and external system in planned economy mode, unfavorable forthe development of higher education, so hinders the furtherimprovement of undergraduate teaching quality of traditional Chinese medicine.

The second is the contradiction betweenthe further growth of enrollment scale and education investment. The enrollment scale of modern Chinese medicine colleges and universities is constantly improving, but the government investment is relativelyslow, so that teaching resources in some local colleges and universities of traditional Chinese medicine lack ${ }^{[1]}$.

University management system and concept

First of all, the level of teaching management. Some colleges and universities of traditional Chinese medicine attach great importance to diploma in the aspect of personnel, thus they ignore a series of humanized heat certificates such as talent management ability, professional ethics and affinity,reducing the training quality of Chinese medicine talents.

Secondly, the concept of education management lags behind. The training mode and goal of some Chinese medical colleges and universities are single and deviated from the development needs of modern society.In some places, the talent training mode of medical colleges and universities cannot meet the demands of the modern society for the all-round talents and the innovative talents.The theories of teaching management with teachers and teaching as core is backward, and the teaching management system is not perfect and not fully implements the center position of teaching .

Finally, the problems of teaching quality and monitoring mechanism. Some colleges and universities of traditional Chinese medicine lack the corresponding self restraint mechanism in the improvement of teaching quality, and most of the teaching quality evaluation is random inspection and treatment of emergencies, lackingthe corresponding whole process monitoring and institutionalized security system.

Main aspects of colleges and Universities

First of all, there is a shortage of teachers in traditional Chinese medicine. In the process of expanding enrollment of colleges and universities, the teacher resources of some local colleges and universities of traditional Chinese medicine are particularly scarce, and colleges and universities just attaches importance to scientific research and lacks the work input of undergraduate teaching.

Secondly, students have a shorter time in school.Because to the employment pressure of modern society, the students ignored the study of professional knowledge, causing that undergraduate students have grandiose aims but puny abilities in modern university. Nowadays, unable to meet the demand of the development of modern society in the future ${ }^{[2]}$.

\section{The foundation of the construction of undergraduate teaching quality assurance system in Chinese medical universities}

\section{System structure}

System structurerefers to the framework content of undergraduate teaching in the process of quality guarantee systemconstruction, mainly includes the link and the factorsof undergraduate teaching quality, such as teaching resources management, training management, teaching quality management, teaching quality evaluation, analysis and improvement.

Quality standard

Quality standard refers to the reference standard of framework in the construction process of 
the university undergraduate quality assurance system, including whether the construction of policy is norm, software and hardware resources in the construction process meets the appropriate standards, management agencies and responsibility is sound, management authority clear clear ${ }^{[3]}$. Division of responsibility

It mainly refers to that the undergraduate teaching quality assurance system in the process of construction should achieve the implementation of the project divisionaccording to the frameworkcontent.It means implemented based on the designated unitsto achieve the teachingquality of higher education. For example, the management of teaching team should be achieved according to the personnel department, and the management of university teaching should be implemented according to the academic affairs office.

Institutional framework

It mainly refers to that whether the undergraduate teaching quality assurance system in the constructionprocess of implementation is quippedwith execution and leadership and other institutions.In colleges and universities every frame content of undergraduate teaching quality guarantee system needs to have executor, responsible person and the monitoring staff.The institutional framework can effectively guarantee the comprehensive implementation of the quality assurance system of undergraduate teaching in colleges and universities ${ }^{[4]}$.

\section{Construction of undergraduate teaching quality assurance system in Chinese medicine universities}

Content of teaching quality guarantee system

The quality assurance system of undergraduate teaching in Chinese medicine universities mainly consists of teaching command system, information collection and processing system, evaluation and diagnosis system and information feedback system. All the systemsare interrelated and restricted, and realize the overall control of teaching quality in colleges and universities.

Teaching command system

Teaching command system mainly includes the school curriculum committee, the curriculum construction committee and the committee of experts. This part will realize comprehensive investigation and survey about government management policy and social unit demand, and conduct overall research and deliberation about strategic development planning, teaching training objectives and important issues in the operation process, such as setting the teaching goal,the order in the teaching operation process, so as to provide suggestions for college decision-making, effectively improve the decision-making level of educationteaching ${ }^{[5]}$.

Information collection and processing system

The information collection and processing system mainly includes teaching quality monitoring center, student teaching management committee and the teaching supervision committee.According to the teaching lesson and the symposium mode, the department will fully grasp the problems of the interaction between teachers and students, students' study style and teachers in the implementation of the teaching planinthe teaching process, and then collect all the information of school in the teaching process. After that, it will organize and implement the inspection and evaluation of the school teaching work, then summarize and analyze all the information in a comprehensive way, ensuring the smooth flow of the school quality testing information channel.

Evaluation and diagnosis system

The evaluation and diagnosis system is mainly to realize the evaluation and diagnosis in the teachingcourse of undergraduate, and then make a comprehensive summary and analysis of the corresponding improvement programs, so as to provide the corresponding guidance suggestions for the comprehensive reform of the education and teaching and the improvement of teaching quality in colleges and universities ${ }^{[6]}$.

Information feedback system

In the process of improving the teaching quality monitoring and diagnosis system, Chinese medicine university should create perfect feedbacksystem, such as selective examination system of teaching plans, survey system of graduate student quality, workable recommendations of teaching 
plans, but also make the teaching units fully implement teaching perfected measures, then track the effect. After that, it will implement network student assessment system perfection, so that the school teaching units, management departments and teachers are able to participate in the teaching management in colleges and universities, so as to fully grasp the running situation of the teaching work in colleges and universities.

Promote the standardization and normalization in the teaching process

The first is to establish the teaching operation management mechanism. The school should organize teaching management files regularly, improve the implementation of teaching management rules and regulations, specification of student course selection, query results, clinical practice and other aspects, so as to improve the normalization of undergraduate teaching, and effectively strengthen the service consciousness of teachers in colleges and universities, effectively improve the efficiency of teaching management. Moreover, we will standardize the creation of the college and the teaching and research office, realize the improvement of relevant documents, and carry out corresponding teaching inspection according to the experts. Through the above measures, the school will give full play to the enthusiasm of teachers, administrators and students, and create a perfect teaching quality assurance system, to realize the standardized development of school teaching management, and to lay a good foundation for the long-term development of higher education in colleges and universities.

Secondly, we should establish a standardized teaching quality system. The standard construction of teaching link quality is taken as the basis to form a system framework of training standard, teaching process management standard, professional setting standard and teaching result evaluation standard of Chinese medicine personnel. In the cultivation processof innovative talents in traditional Chinese medicine, according to the development of Chinese medicine and the social demand for talents, we should realize the professional structure adjustment, so as to ensure the traditional Chinese medicine as the core, and to realize the expansion of the relevant new disciplinesthrough the corresponding argument, which becomes the standard process set by theprofessionalmanagement settings.

And the school should also pay attention to the training and management of teaching body, improve the admission requirements of young teachers and the opportunities of teachers' further study, training and further study, and encourage teachers to invest in teaching research, so as to effectively improve teachers' innovative consciousness and discipline construction level. Based on the management experience of complete credit system, the school creates evaluation standards of teaching effectiveness, classroom teaching, quality of graduates and clinical probation and other aspects, so as to realize the diagnosis and evaluation of the teaching quality of modern education and teachingreform ${ }^{[7-8]}$.

\section{Conclusion}

The undergraduate teaching quality guarantee system not only includes the university level, but also includes the teaching quality guarantee system in the hospital level. In modern society, how to achieve the guarantee of the teaching quality is particularly important content. We should achieve the creation principleof quality assurance system of undergraduate teaching in colleges and universities, and conduct a comprehensive analysis of the teaching quality andguarantee content, so as to effectively improve the creating quality of undergraduate teaching quality assurance system, and implement high quality and efficiencyofuniversity undergraduate teaching quality guarantee system in the operation process, so as to effectively improve the quality of the education teaching work in colleges and universities.

\section{References}

[1] Liu Chaosheng, Deng Changqing, He Qinghu.etc. "undergraduate teaching engineering"Review and Reflection on undergraduate education of integrated traditional Chinese and Western medicine from the perspective of undergraduate teaching project construction[J]. Chinese Medicine Modern 
Distance Education of China, 2013, 11(20):92-94.

[2] Yang Lin,Liu Yiyang, Zhangyang.etc. Research and practice of quality assurance system construction in traditional Chinese medicines colleges and Universities -- Based on the undergraduate teaching quality report release system [C]// "decision Forum -- management decision model application and analysis seminar" (Part Two). 2016.

[3] Jiang Bo, Yang Kaili, Wang Yan.Model Constructing of the Physical Education Teaching Quality Guaranteeing System:An Empirical Study of Tongji University[J]. Journal of National Academy of Education Administration. 2017(6):82-89.

[4] Zhao Jushan, Qi Lingling. Practical exploration on the construction of internal teaching quality guarantee system in colleges and universities[J]. Education Exploration, 2009(3):65-66.

[5]Jiang Xiuli, Su Lianjiang. Research and Exploration on the construction of teaching quality guarantee system in newly established universities[J]. Heilongjiang Researches on Higher Education, 2014(1):74-76.

[6] Li Yongmei. On the construction of undergraduate education quality guarantee system_—From the perspectives of survival and growth of the newly built 4-Year program colleges and universities[J]. Journal of Neijiang Normal University,2013, 28(6):93-96.

[7] Shang Bing, Cong Peiwei. Exploration and practice of improvement of the long term mechanism of teaching quality assurance system[J]. Chinese Medicine Modern Distance Education of China, 2013, 11(5):84-85.

[8] Yan Xiujuan. Construction and development of part-time teaching supervision team in higher Chinese medicine colleges[J]. JournalofTraditionalChineseMedicineManagement, 2017(11):28-29.

Author: Bi Yan (1980-), male (Han), Jilin Nong'an, assistant researcher in Changchun University of Traditional Chinese Medicine, Ph.D., engaged in the teachingresearch of Chinese medicine education. Cell phone: 13756553287

Communication Author: Yue Donghui (1979-), female (Han), Jilin Changchun, associate professor of Changchun University of Traditional Chinese Medicine,

Master degree tutor, doctoral advisor, Ph.D.,engaged in the teachingresearch of Chinese medicine education in epidemic febrile disease .

Address: JingyueEconomic Development Zone, Changchun, Jilin province, No. 1035 on Boshuo Road, higher education research center of Changchun University of Traditional Chinese Medicine. Zip code: 130117 